\title{
CORRIGENDUM
}

\section{High-performance lithium-ion anodes using a hierarchical bottom-up approach}

A. Magasinski, P. Dixon, B. Hertzberg, A. Kvit, J. Ayala and G. Yushin

Nature Materials 9, 353-358 (2010); published online: 14 March 2010; corrected after print: 19 March 2010.

In the version of this Article originally published, the surname of A. Magasinski was spelled incorrectly. This has been corrected in the HTML and PDF versions of this Article. 